National Water-Quality Assessment Program

Prepared in cooperation with the Conservation Technology Information Center

\title{
Tillage Practices in the Conterminous United States, 1989-2004-Datasets Aggregated by Watershed
}

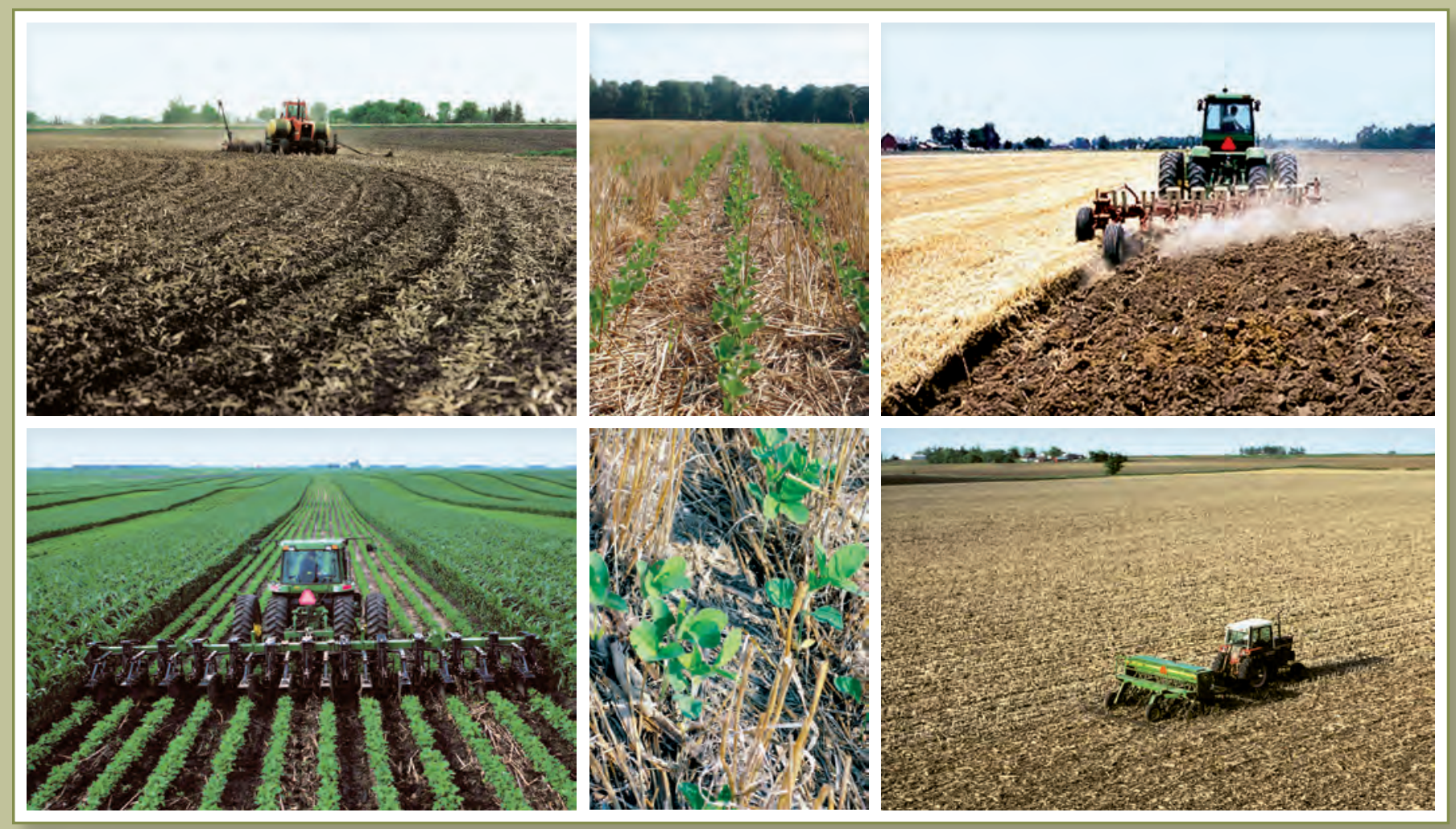

Data Series 573

U.S. Department of the Interior

U.S. Geological Survey 


\section{Cover photos}

Upper Left. Conservation tillage system (full width) that leaves at least 30 percent of the soil covered after planting with last year's crop residue (mulch tillage). Central lowa. Photograph by Lynn Betts, 1999,

Natural Resources Conservation Service Photo Gallery, NRCSIA99097, http://photogallery.nrcs.usda.gov/.

Lower Left. Ridge-till and strips of corn and soybeans in northwest lowa field. Photograph by Lynn Betts, 1999, Natural Resources Conservation Service Photo Gallery, NRCSIA99311, http://photogallery.nrcs.usda.gov/.

Upper and Lower Center. No-till soybeans. Photos courtesy of Conservation Technology Information Center, Feb. 2011, http://www.ctic.org/.

Upper Right. Moldboard plowing. Stages of Bean Growth - Plowing, Michigan State University, AgBioResearch, http://agbioresearch.msu.edu/saginawvalley/Pic_Tour/plowing.htm accessed Feb. 2011.

Lower Right. No-till drill working in central lowa. Photograph by Tim McCabe, 1999, Natural Resources

Conservation Service Photo Gallery, NRCSIA99091, http://photogallery.nrcs.usda.gov/. 


\section{Tillage Practices in the Conterminous United States, 1989-2004- Datasets Aggregated by Watershed}

By Nancy T. Baker

National Water-Quality Assessment Program

Prepared in cooperation with the Conservation Technology Information Center

Data Series 573

U.S. Department of the Interior

U.S. Geological Survey 


\title{
U.S. Department of the Interior \\ KEN SALAZAR, Secretary \\ U.S. Geological Survey \\ Marcia K. McNutt, Director
}

\section{U.S. Geological Survey, Reston, Virginia: 2011}

\author{
For more information on the USGS — the Federal source for science about the Earth, its natural and living resources, \\ natural hazards, and the environment, visit http://www.usgs.gov or call 1-888-ASK-USGS \\ For an overview of USGS information products, including maps, imagery, and publications, \\ visit http://www.usgs.gov/pubprod \\ To order this and other USGS information products, visit http://store.usgs.gov
}

\begin{abstract}
Any use of trade, product, or firm names is for descriptive purposes only and does not imply endorsement by the U.S. Government.

Although this report is in the public domain, permission must be secured from the individual copyright owners to reproduce any copyrighted materials contained within this report.
\end{abstract}

Suggested citation:

Baker, N.T., 2011, Tillage practices in the conterminous United States, 1989-2004-Datasets Aggregated by Watershed: U.S. Geological Survey Data Series 573, 13 p. 


\section{Foreword}

The U.S. Geological Survey (USGS) is committed to providing the Nation with reliable scientific information that helps to enhance and protect the overall quality of life and that facilitates effective management of water, biological, energy, and mineral resources (http://Www.usgs.gov/). Information on the Nation's water resources is critical to ensuring long-term availability of water that is safe for drinking and recreation and is suitable for industry, irrigation, and fish and wildlife. Population growth and increasing demands for water make the availability of that water, measured in terms of quantity and quality, even more essential to the long-term sustainability of our communities and ecosystems.

The USGS implemented the National Water-Quality Assessment (NAWQA) Program in 1991 to support national, regional, State, and local information needs and decisions related to water-quality management and policy (http://water.usgs.gov/nawqa). The NAWQA Program is designed to answer: What is the quality of our Nation's streams and groundwater? How are conditions changing over time? How do natural features and human activities affect the quality of streams and groundwater, and where are those effects most pronounced? By combining information on water chemistry, physical characteristics, stream habitat, and aquatic life, the NAWQA Program aims to provide science-based insights for current and emerging water issues and priorities. From 1991 to 2001, the NAWQA Program completed interdisciplinary assessments and established a baseline understanding of water-quality conditions in 51 of the Nation's river basins and aquifers, referred to as Study Units (http://water.usgs.gov/nawqa/studies/study_units.htm).

National and regional assessments are ongoing in the second decade (2001-2012) of the NAWQA Program as 42 of the 51 Study Units are selectively reassessed. These assessments extend the findings in the Study Units by determining water-quality status and trends at sites that have been consistently monitored for more than a decade, and filling critical gaps in characterizing the quality of surface water and groundwater. For example, increased emphasis has been placed on assessing the quality of source water and finished water associated with many of the Nation's largest community water systems. During the second decade, NAWQA is addressing five national priority topics that build an understanding of how natural features and human activities affect water quality, and establish links between sources of contaminants, the transport of those contaminants through the hydrologic system, and the potential effects of contaminants on humans and aquatic ecosystems. Included are studies on the fate of agricultural chemicals, effects of urbanization on stream ecosystems, bioaccumulation of mercury in stream ecosystems, effects of nutrient enrichment on aquatic ecosystems, and transport of contaminants to public-supply wells. In addition, national syntheses of information on pesticides, volatile organic compounds (VOCs), nutrients, trace elements, and aquatic ecology are continuing.

The USGS aims to disseminate credible, timely, and relevant science information to address practical and effective water-resource management and strategies that protect and restore water quality. We hope this NAWQA publication will provide you with insights and information to meet your needs, and will foster increased citizen awareness and involvement in the protection and restoration of our Nation's waters.

The USGS recognizes that a national assessment by a single program cannot address all water-resource issues of interest. External coordination at all levels is critical for cost-effective management, regulation, and conservation of our Nation's water resources. The NAWQA Program, therefore, depends on advice and information from other agencies—Federal, State, regional, interstate, Tribal, and local—as well as nongovernmental organizations, industry, academia, and other stakeholder groups. Your assistance and suggestions are greatly appreciated. 


\section{Acknowledgments}

The author thanks Karen Scanlon, Executive Director, and the staff of the Conservation Technology Information Center (CTIC) for providing the county-level tillage practice dataset and for providing technical support during the data-aggregation process. The author also expresses gratitude to two CTIC consultants: Dan Towery of Ag Conservation Solutions for explaining the methods used to collect the data and Scott Brunton of EsJay Computer Systems for providing database technical support. 


\section{Contents}

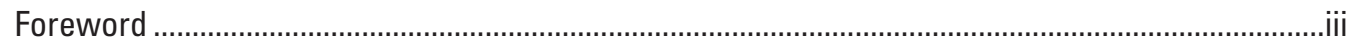

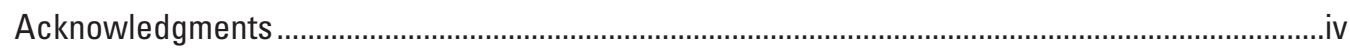

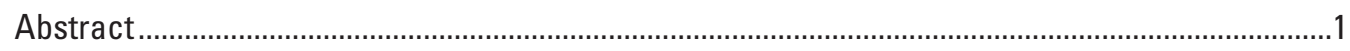

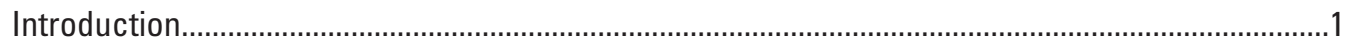

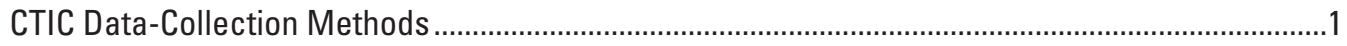

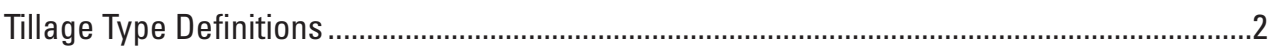

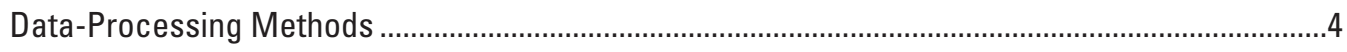

Preprocessing of County-Level Tillage Data .........................................................................

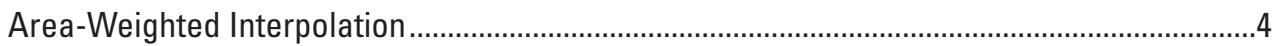

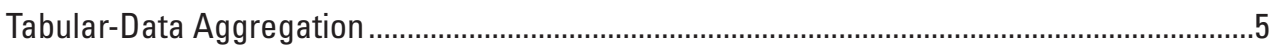

Tillage-Practice Datasets Aggregated to 8-Digit Hydrologic Unit Watersheds................................8

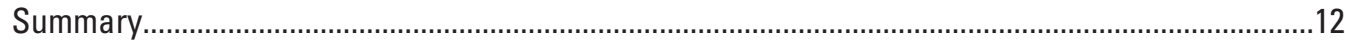

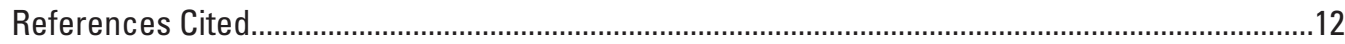

Appendix 1. Tillage Practices in the Conterminous United States, 1989-2004 based on the 1992 enhanced National Land Cover Data; dBase file: tillage_lug2e.

Appendix 2. Tillage Practices in the Conterminous United States, 1989-2004 based on the 2001 National Land Cover Data; dBase file: tillage_lu01...

Appendix 3. Companion dataset to be used with the tabular $\mathrm{dBase}$ tillage

practice datasets, dBase file: tillage_lug2e and dBase file: tillage_lu01. .13

\section{Figures}

1-2. Maps showing:

1. States where tillage information was obtained by roadside-transect surveys for 2000, 2002 and 2004, and location of cultivated land

2. Last year for which the Crop Residue Management Survey was conducted, by county, for the $A$ 1989-98, B 1998 and 2000, and $C$ 2002, 2004 and 2006-08 time periods for the conterminous United States

3. Land-cover weighted areal interpolation by (1) overlaying 8-digit hydrologic unit watersheds with (2) cultivated cropland and (3) county boundaries resulting in (4) the intersection of cultivated land for all the counties in each watershed. Examples of the process are shown for areas in the $A$ western and $B$ eastern United States

4. Maps showing the comparison of the original Conservation Technology Information Center county-level data and 8-digit hydrologic unit watershed-level data for the percentage of no-till on $A$ all crops, $B$ corn, and $C$ soybeans for the conterminous United States, 2004

5. Graphs showing the comparison of Economic Research Service (E) and Conservation Technology Information Center (C) estimates of total planted acreages, by State, and tillage practice for corn for 1993, 1996, 1998, and 2000. 


\section{Tables}

1. Example output from U.S. Geological Survey National Water-Quality Assessment Area Characterization, Feature Weights to Table Tool. .7

2. Attribute labels and definitions for tillage_lu92e.dbf and tillage_lu01.dbf. .8

\section{Conversion Factors and Abbreviations}

\begin{tabular}{lcl}
\hline \multicolumn{1}{c}{ Multiply } & By & \multicolumn{1}{c}{ To obtain } \\
\hline inch (in.) & Length & \\
inch (in.) & 2.54 & centimeter $(\mathrm{cm})$ \\
meter (m) & 25.4 & millimeter $(\mathrm{mm})$ \\
meter (m) & 3.281 & foot $(\mathrm{ft})$ \\
mile, nautical (nmi) & 1.094 & kilometer $(\mathrm{km})$ \\
yard (yd) & 1.852 & kilometer $(\mathrm{km})$ \\
\hline & 0.9144 & yard (yd) \\
\hline acre & \multicolumn{1}{c}{ Area } & \\
acre & 4,047 & square meter $\left(\mathrm{m}^{2}\right)$ \\
acre & 0.4047 & hectare $(\mathrm{ha})$ \\
acre & 0.4047 & square hectometer $\left(\mathrm{hm}^{2}\right)$ \\
square mile $\left(\mathrm{mi}^{2}\right)$ & 0.004047 & square kilometer $\left(\mathrm{km}^{2}\right)$ \\
square mile $\left(\mathrm{mi}^{2}\right)$ & 259.0 & hectare $($ ha) \\
\hline
\end{tabular}

\section{Abbreviations used in this report}

$\begin{array}{ll}\text { CTIC } & \text { Conservation Technology Information Center } \\ \text { ERS } & \text { Economic Research Service } \\ \text { FWT } & \text { feature weights to table } \\ \text { HU } & \text { hydrologic unit } \\ \text { NACT } & \text { NAWQA Area Characterization Toolbox } \\ \text { NASS } & \text { National Agricultural Statistics Service } \\ \text { NAWQA } & \text { National Water-Quality Assessment } \\ \text { NLCD } & \text { National Land Cover Data } \\ \text { NRCS } & \text { Natural Resources Conservation Service } \\ \text { USDA } & \text { U.S. Department of Agriculture } \\ \text { USGS } & \text { U.S. Geological Survey } \\ \text { WAREAF } & \text { area-weighted fraction }\end{array}$




\title{
Tillage Practices in the Conterminous United States, 1989-2004-Datasets Aggregated by Watershed
}

\author{
By Nancy T. Baker
}

\begin{abstract}
This report documents the methods used to aggregate county-level tillage practices to the 8-digit hydrologic unit (HU) watershed. The original county-level data were collected by the Conservation Technology Information Center (CTIC). The CTIC collects tillage data by conducting surveys about tillage systems for all counties in the United States. Tillage systems include three types of conservation tillage (no-till, ridge-till, and mulch-till), reduced tillage, and intensive tillage. Total planted acreage for each tillage practice for each crop grown is reported to the CTIC. The dataset includes total planted acreage by tillage type for selected crops (corn, cotton, grain sorghum, soybeans, fallow, forage, newly established permanent pasture, spring and fall seeded small grains, and "other" crops) for 1989-2004.

Two tabular datasets, based on the 1992 enhanced and 2001 National Land Cover Data (NLCD), are provided as part of this report and include the land-cover area-weighted interpolation and aggregation of acreage for each tillage practice in each 8-digit HU watershed in the conterminous United States for each crop. Watershed aggregations were done by overlying the 8-digit HU polygons with a raster of county boundaries and a raster of either the enhanced 1992 or the 2001 NLCD for cultivated land to derive a county/land-cover area weighting factor. The weighting factor then was applied to the countylevel tillage data for the counties within each 8-digit $\mathrm{HU}$ and summed to yield the total acreage of each tillage type within each 8-digit HU watershed.
\end{abstract}

\section{Introduction}

The Conservation Technology Information Center (CTIC) has made its proprietary county-level tillage survey available for inclusion in U.S. Geological Survey (USGS), National Water-Quality Assessment (NAWQA) supported analyses. The dataset includes planted acreage of conservation tillage (no-till, ridge-till, and mulch-till), reduced tillage, and intensive or conventional tillage for selected crops (corn, cotton, grain sorghum, soybeans, fallow, forage, newly established permanent pasture, spring and fall seeded small grains, and "other" crops), by county, for 1989-2004. The CTIC requests that the data not be distributed in their raw form - county acreage totals, by crop, for each tillage practice - because the survey is proprietary. To comply with the CTIC requirements, the dataset was aggregated by watershed for each tillage practice, crop, and year combination. Watershed aggregations were made for each 8-digit hydrologic unit (HU) in the conterminous United States by using an area-weighted interpolation for cultivated land in each county intersecting a HU.

This report documents the methods used by the CTIC to collect tillage data and the methods used by the USGS to prepare the CTIC data for release for NAWQA-supported analyses. The prepared datasets are provided as part of this report and include the land-cover area-weighted interpolation and aggregation of acreage for each tillage practice in each 8-digit HU watershed in the conterminous United States for corn, cotton, grain sorghum, soybeans, fallow, forage, newly established permanent pasture, spring seeded and fall seeded small grains, and other crops (sum of all other crops not listed). Land-cover area-weighted interpolations were done using both the 1992 (enhanced) (Nakagaki and others, 2007) and 2001 (LaMotte, 2008) National Land Cover Data (NLCD) resulting in two tabular datasets. The prepared tabular datasets include tillage practices for 1989-2004 for all counties (aggregated to the 8-digit HU) where data were collected in the conterminous United States. The CTIC did not conduct surveys for 1999, 2001, and 2003. In addition, surveys were not conducted every year for 1995-98 for several counties; therefore, the number of years data were collected varies by county. A spatial coverage of the 8-digit HUs, which can be related to the two tabular datasets based on the 8-digit HU code, also is included in this report.

\section{CTIC Data-Collection Methods}

The CTIC collects tillage data by conducting surveys about tillage systems for all counties in the United States. Tillage systems include three types of conservation tillage (no-till, ridge-till, and mulch-till), reduced tillage, and intensive tillage. Total annually planted crop acreage for each tillage practice for each crop grown is reported by local conservationists to the CTIC. For 1989-98, surveys were based on local knowledge and expertise to "best estimate" tillage practices. Local conservation partnerships included Natural Resources Conservation Service (NRCS), State Soil and Water Conservation Districts, State extension agents, Farm Service Agency, and other agribusiness partners. For 
2000, 2002, and 2004, 17 States (fig. 1) used roadside-transectsurvey procedures for counties with more than 100,000 acres of cropland. County conservation staff drove along a set course through areas dominated by cropland; staff collected data on approximately 480 fields in each county. Percentages of each crop/tillage system were calculated and applied to total county crop acreages based on a combination of local knowledge of county crop acreage (Conservation Technology Information Center, 2004) and acreage estimated by the U.S. Department of Agriculture, National Agricultural Statistics Service (NASS) (Carmen Sandretto, U.S. Department of Agriculture, Economic Research Service, written commun., 2010). The CTIC roadside-transect-survey methods are described in the 2004 Cropland Roadside Transect Survey document (Conservation Technology Information Center, 2004).

Not all counties reported tillage information every year. Figure 2 shows the CTIC survey years and the actual years data were collected in each county. All counties reported tillage information for 1989-95. For 1996-98, most counties reported tillage information; exceptions include counties in the desert southwest, coastal northeast, West Virginia, and in several States throughout the U.S. - primarily in counties with less than 25,000 cropland acres. Most counties reported tillage information for 2000, 2002, and 2004; selected areas in the Midwest reported tillage information for 2006-08 (fig. 2). The 2006-08 data are not included in this report because they are so sparse.

\section{Tillage Type Definitions}

Tillage systems are defined based upon the amount of crop residue that remains on the soil after planting and resulting disturbance to the soil. Tillage types are defined in the CTIC 2004 National Crop Residue Management Survey.

Conservation tillage is any cropland system that leaves at least one-third of the soil covered with crop residue after planting. Conservation tillage types include no-till/strip-till, ridge-till, and mulch-till.

- The no-till concept has evolved as technology has changed. With no-till, producers disturb only the minimal amount of soil needed to ensure a good stand and yield. Variations under the no-till umbrella include the following:

- Midwest strip-till usually involves a mole knife to till a zone approximately 10 inches wide and 4 to 5 inches high in the fall. Some combination of nutrients is usually applied at the same time. The following spring, planting occurs in the tilled strip.

- Southeast strip-till is used on the Sandy Coastal Plain soils (soils that naturally compact) in the Southeast portion of the United States. A ripper runs about 14 inches deep ahead of or with the planter.

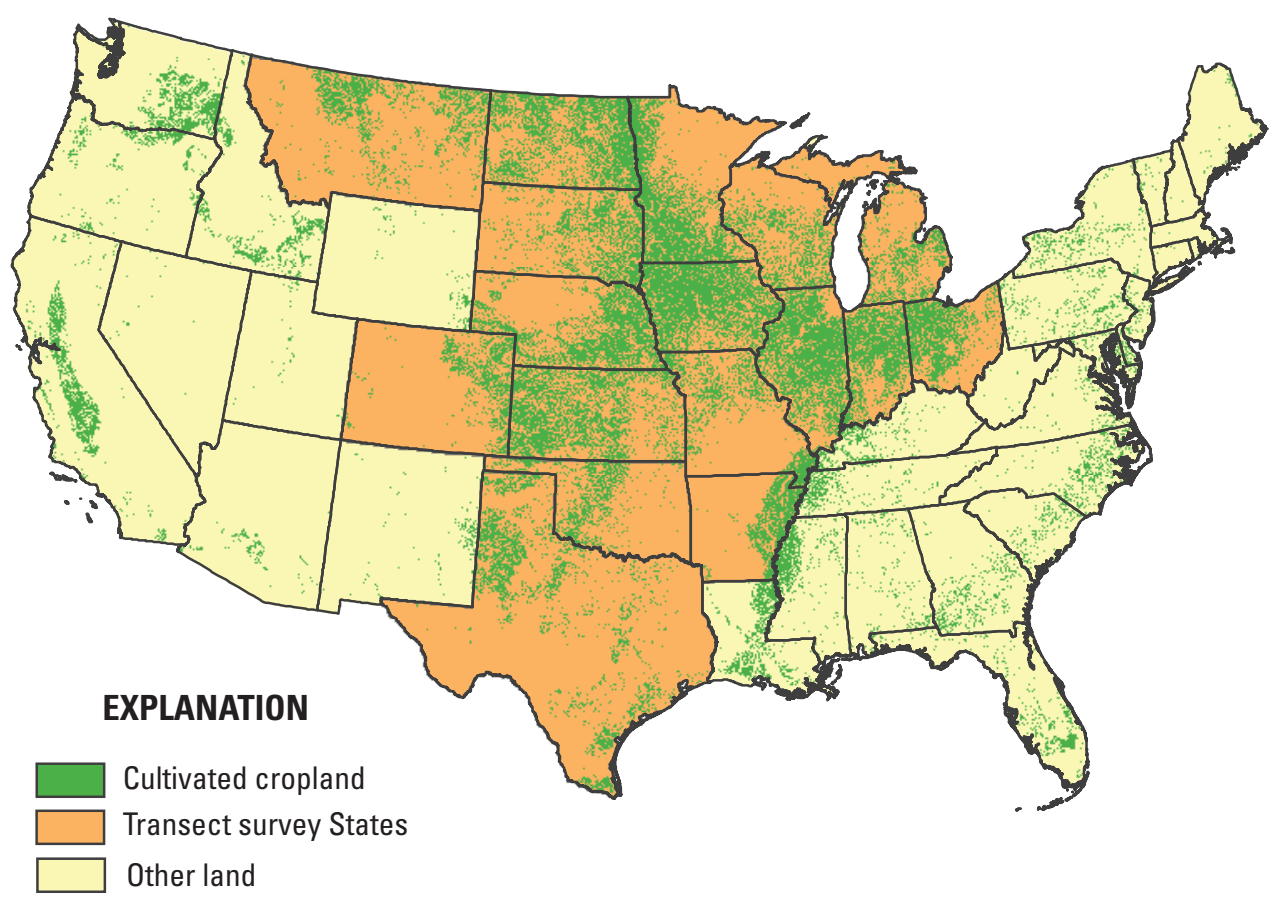

Figure 1. States where tillage information was obtained by roadside-transect surveys for 2000, 2002 and 2004, and location of cultivated land. Transects were surveyed in counties with more than 100,000 acres of cropland. [Source: Conservation Technology Information Center, 2004] 
- Vertical tillage is used with a narrow ripper about 12 to 14 inches deep, usually in the fall, which causes very little surface soil disturbance. Planting occurs directly over the tilled strip.

- Fluffing harrows "fluff" the residue, allowing excess moisture in the seedbed to evaporate and improve planting conditions.

Other conservation tillage practices include the following:

- Ridge-till involves building 4- to 6-inch high ridges during row cultivation and scraping off 1 to 2 inches of the ridge during planting.

- Mulch-till is a full-width (100 percent of soil surface disturbed) tillage system that usually involves one to three tillage passes. Implements such as chisel plows, disks, field cultivators and combination tools are used.
No-till (including all variations mentioned), ridge-till, and mulch-till fall under the conservation tillage umbrella.

\section{NOT Conservation Tillage}

- Reduced-till systems are somewhat similar to mulch till in that they involve full-width tillage, use the same implements and may use one to three tillage trips. Reduced-till, however, leaves 15-30 percent residue on the soil surface after planting.

- Intensive-till or conventional-till involves full-width tillage and may involve one to three or perhaps up to 15 tillage passes. There is less than 15 percent residue on the soil surface after planting. Moldboard plowing and/or multiple tillage trips are considered the same. (Conservation Technology Information Center, 2004, http://www.ctic.purdue.edu/media/pdf/TillageDefinitions.pdf)
$\boldsymbol{A}$

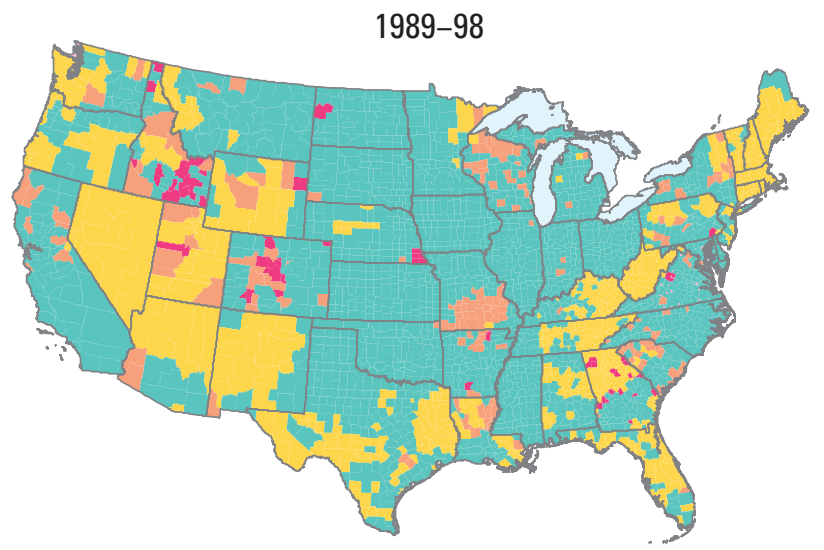

C

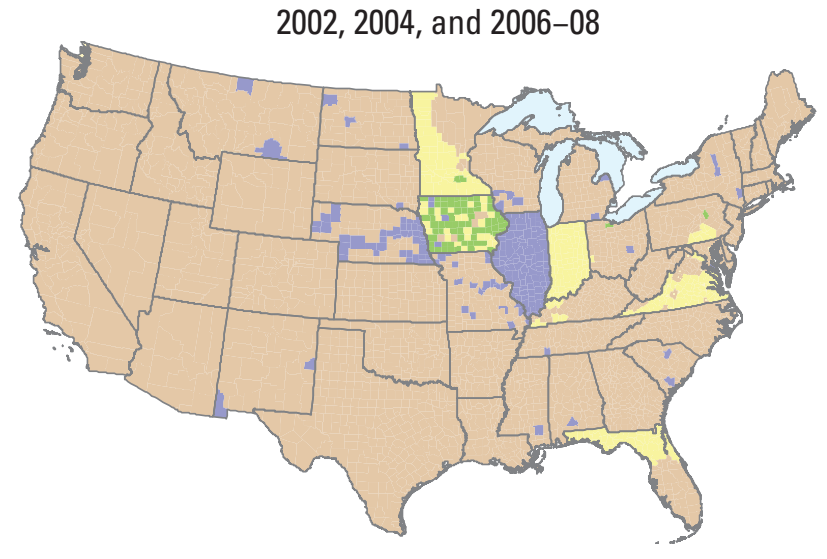

B

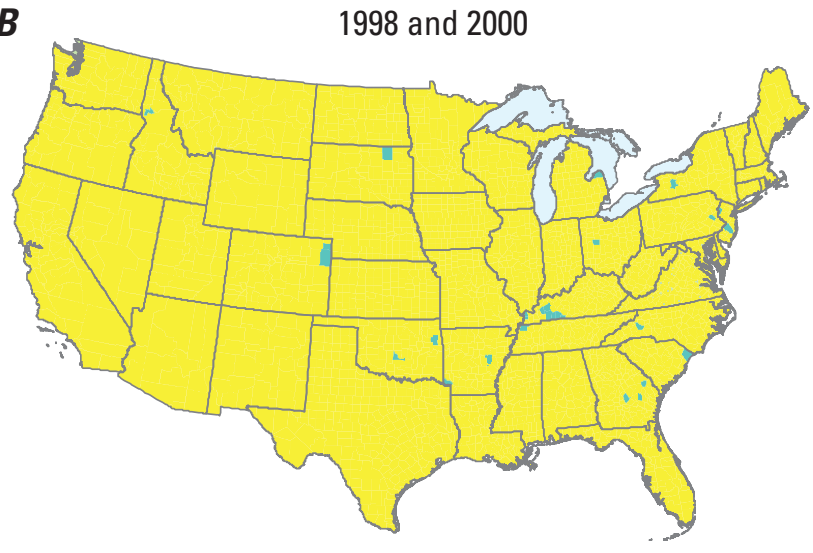

EXPLANATION

Last year for which the Crop Residue Management Survey was conducted, by county, for the time period
A All counties reported in 1989-95

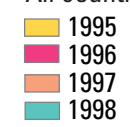
B No counties reported in 1999 $\square 1998$
C All counties reported in 2002 and 2004 No counties reported in 2001 or 2003 $\square \quad 2004$
$\square \quad 2006$
$\square \quad 2007$
$\square \quad 2008$

Figure 2. Last year for which the Crop Residue Management Survey was conducted, by county, for the $A 1989-98, B 1998$ and 2000, and $C$ 2002, 2004 and 2006-08 time periods for the conterminous United States. [Source: Conservation Technology Information Center, 2004] 
The CTIC collects tillage information for all annually planted crops and for compilation purposes sums the acreage into the following major crop categories: full season and double cropped corn, grain sorghum, and soybeans; cotton; forage crops; spring seeded and fall seeded small grains; fallow; newly established permanent pasture; and other crops including vegetables. Starting in 2000, the CTIC eliminated the reporting requirement for double cropping of corn and grain sorghum because these two categories represented a fairly small acreage, and there was inconsistency in reporing these acreages. By definition, double cropped means two principal row crops in one growing season. Many times corn or sorghum was planted after hay or wheat was harvested. There were few acreages that were double cropped and the CTIC decided to simplify the data collections where possible; therefore, they no longer were counted as a separate category and were subsequently combined with the total full-season acreages (Dan Towery, Conservation Technology Information Center, written commun., 2010).

Small grains are grouped into spring seeded and fall seeded. Spring seeded small grains include rice, spring wheat, oats, and barley. Fall seeded small grains include winter wheat and rye. All acreages of small grains are counted in the year they are seeded. Forage crops also are reported in the seeding year only (Dan Towery, Conservation Technology Information Center, written commun., 2010).

Other crops include other vegetable crops, truck crops, peanuts, potatoes, tobacco, beans, canola, sugar beets, sugarcane, sunflowers, and any other crop not included in the major crop categories (Conservation Technology Information Center, 2004). Tillage practices also were reported for fallow land and newly established permanent pasture. Ridge-tillage is not applicable to either of these planting practices.

\section{Data-Processing Methods}

The USGS may not distribute the CTIC tillage data in its raw form - a tabular dataset of county acreage totals, by crop, for each tillage practice - because the data are proprietary. The following steps were taken to prepare the tillage data for distribution and analysis. First, the original tabular county-level dataset was preprocessed to check for outliers. Next, landcover area-weighting factors were generated to determine the area of cultivated land within each county/8-digit HU watershed combination. Finally, the land-cover weighting factors were applied to the CTIC reported acreages of tilled land for each crop and tillage practice and aggregated to the 8-digit HU watershed by summing the acreage for each county portion that falls within each watershed.

\section{Preprocessing of County-Level Tillage Data}

Prior to land-cover weighting and data aggregation, the original CTIC dataset was checked for data values that were outside the range of probable values. Initially, the entire dataset was checked for negative values. Eleven cases were found and brought to the attention of the CTIC, who then supplied corrected values (Scott Brunton, Conservation Technology Information Center, written commun., 2009). The data also were checked to see if, for any given year, the total acreage for all tillage practices for each crop in each county was greater or less than three times the standard deviation of the values for the entire period of record. A small percentage of the data $(109$ cases out of 445,248$)$ were greater or less than three times the standard deviation. These outliers were evaluated on an individual basis to determine whether to keep the original data value or to replace the original data value with an interpolated data value from previous and subsequent years. There were 57 cases where the data values were suspect enough to warrant replacing the original data values.

\section{Area-Weighted Interpolation}

A land-cover area-weighted interpolation for cultivated land was done to determine the weighting factors needed to aggregate county-level tillage data to the 8-digit HU watershed. Weighting factors were generated based on the area of cultivated land within each county/8-digit HU watershed combination. The spatial datasets used to perform the interpolation include the Water Boundary Dataset (U.S. Geological Survey and U.S. Department of Agriculture-Natural Resources Conservation Service, 2009), the enhanced NLCD for 1992 (Nakagaki and others, 2007) and NLCD 2001 (LaMotte, 2008), and the 30-m resolution grid of the 1990 county boundaries (JoAnn Gronberg, U.S. Geological Survey, written commun., 2005) (fig. 3). Land-cover weighting is used so that countylevel tillage data are proportioned to the agricultural areas in each county/8-digit HU watershed. With a simple area-weighted interpolation, the tillage data would be proportioned equally throughout the county; therefore, it is not the best method for counties where the majority of cultivated land may be concentrated in a small portion of the county.

The 8-digit HU watershed boundaries used for this aggregation were derived from the Water Boundary Dataset-12-digit HU (U.S. Geological Survey and Natural Resources Conservation Service, 2009). The 12-digit HU subwatershed polygons were dissolved to the 8-digit HU watershed level for the conterminous United States. The average size of a $\mathrm{HU}$ is $40 \mathrm{mi}^{2}$ for a 12-digit watershed and $700 \mathrm{mi}^{2}$ for an 8-digit watershed (U.S. Geological Survey and U.S. Department of AgricultureNatural Resources Conservation Service, 2009).

Land-cover areal weighting was done using both the 1992 (enhanced) and 2001 NLCD 30-m resolution raster data (NLCDe 92 and NLCD01, respectively), resulting in two separate sets of area-weighting factors. The CTIC tillage data span from 1989 through 2004, and the generation of the two datasets allows users to decide which land-cover aggregation-NLCDe 92 or NLCD01-is appropriate for their particular analysis. Users are cautioned that direct comparison of NLCDe 92 and NLCD01 is not recommended because these two independently created land-cover products were developed using different methodologies and sources of input data 
(U.S. Geological Survey, 2008a). For example, using NLCDe 92 for areal weighting for earlier years of tillage data and using NLCD01 for the remaining years of tillage data may introduce bias unrelated to changes in tillage practices.

Cultivated land is defined differently for NLCDe 92 and NLCD01. For NLCDe 92, cultivated land includes the following land-cover codes (U.S. Geological Survey, 2010): 61 and 62 classified as Orchards/Vineyards/Other-Orchards, vineyards, and other areas planted or maintained for the production of fruits, nuts, berries, or ornamentals (both 61 and 62 indicate the same land cover -62 is derived from other data sources and is part of the enhancements made to NLCD92); 82 classified as Row Crops-Areas used for the production of crops such as corn, soybeans, vegetables, tobacco, and cotton; 83 Classified as Small Grains-Areas used for the production of graminoid crops such as wheat, barley, oats, and rice; and 84 Classified as FallowAreas used for the production of crops that do not exhibit visible vegetation as a result of being tilled in a management practice that incorporates prescribed alternation between cropping and tillage. The rational for including fallow land is that the NLCD is a snapshot of land cover for a single year. An assumption was made that fallow land will alternate in and out of production and will be actively managed some of the time. In addition, the CTIC tillage data include acreage for fallow land that has been tilled. For NLCD01, cultivated land includes land cover code 82 Cultivated Crops-Areas used for the production of annual crops such as corn, soybeans, vegetables, tobacco, and cotton, and also perennial woody crops such as orchards and vineyards. This class also includes all land being actively tilled (U.S. Geological Survey, 2008b).

A 30-m resolution grid of the 1990 county boundaries (JoAnn Gronberg, U.S. Geological Survey, written commun., 2005) was used as the third component for performing the landcover area-weighted interpolation. The dataset was generated from the 1:100,000-scale polygon coverage of county boundaries for the conterminous United States and was created to generate county statistics such as county weighting factors by land-cover classifications. County weighting factors are used with county data to estimate, for instance, basin-level pesticide application, fertilizer use, and conservation-tillage acres (Naomi Nakagaki, U.S. Geological Survey, written commun., 2010).

Although the size of 8-digit HU watersheds is fairly consistent across the United States, county sizes generally are larger in western states (fig. 3). The disparity in county size in relation to 8 -digit HUs across the country means that the results of aggregating county data to the 8-digit level are different in different areas of the country. In the east, where counties usually are smaller than 8-digit HUs, the resulting acreage for each 8 -digit HU will be the sum of the cultivated land from portions of several counties. Conversely in the west, the resulting acreage for several 8-digit HUs simply may be a proportion of cultivated land in a single county (fig. 3 ).

Cultivated-land area-weighted interpolation was done within the ArcGIS desktop environment (version 9.3.1). A detailed description of the method for calculating landcover area-weighted interpolation is documented in (Naomi
Nakagaki, U.S. Geological Survey, written commun., 2010). The NAWQA Area Characterization Toolbox (NACT) (Price and others, 2010), an add-on toolbox for ArcGIS desktop that automates area-weighted interpolations, was used to obtain the cultivated-land area weights for this report. Using NACT for calculating the interpolation ensures that the steps are performed in a manner consistent with other NAWQA area-weighted interpolations and that standard methods and tolerances for overlaying spatial data are used (Price and others, 2010).

Area weights were calculated using the NACT, Feature Weights to Table (FWT) tool, which calculates the area-weight between the overlapping areas of each feature class against a weight raster and outputs the results to a weight table (table 1) (Price and others, 2010). The FWT tool requires user input for Input Features and associated Input Field, Weight Raster, and Zone Raster. For this interpolation, the Input Features are the 8-digit HU watershed boundary polygons and the associated Input Field is the numeric 8-digit HU code. The Weight Raster is the 30-m resolution grid of the 1990 county boundaries; the Zone Raster is the NLCD. Area-weighting factors are output for each unique 8-digit HU code. For each unique 8-digit HU, a row in the resulting weight table is generated for every county that overlaps each 8-digit HU. Separate weight tables were generated for the NLCDe 92 and NLCD01. The output-weight table entries are split by creating a row for each unique land cover (value of Zone Raster cells) found within the area delineated by each input feature (table 1). The results of the weight table then can be used to proportion tillage acreage for each county/HU based on cultivated land and aggregated for each 8-digit HU.

\section{Tabular-Data Aggregation}

Aggregation of the county-level tillage practice data to the 8-digit HU was done by merging the CTIC county-level data table with the weight table from the land-cover area-weighted interpolation, then multiplying the area-weighted fraction (WAREAF) from the weight table by the acreages for each crop and tillage practice in the county-level data table, and finally summing the resulting acreages for each 8-digit HU.

Aggregation applies to cultivated land, and that data was extracted from the weight tables. For NLCDe 92, this included land-cover codes $61,62,81,82,83$, and 84 . For NLCD01, this included land-cover codes 81 and 82 . For most counties for NLCDe 92, area-weighting factors for 61, 62, 82, 83, and 84 for each county/HU combination were summed before multiplying by the CTIC county-tillage acreages. For NLCD01, the area-weighting factor for land-cover code 82 was used. A small number of counties reported crop acreage and associated tillage practices to CTIC, but there is no NLCD-identified cultivated land in those counties. In those cases, reported crop acreage is weighted by land-cover code 81 . Land-cover code 81 includes Pasture/Hay-Areas of grasses, legumes, or grasslegume mixtures planted for livestock grazing or the production of seed or hay crops. In counties where there was also no NLCD-identified land-cover code 81, the reported crop acreage was proportioned equally throughout the county. 
(1) 8-digit hydrologic unit watershed boundaries

$\boldsymbol{A}$

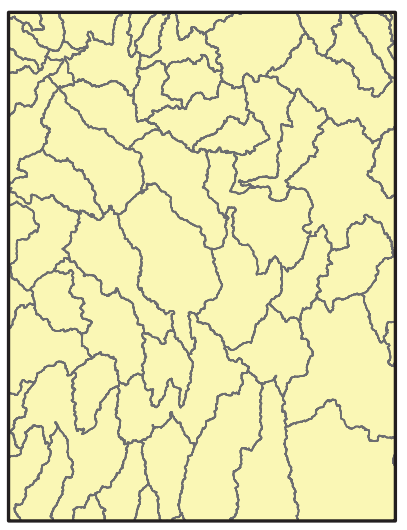

B

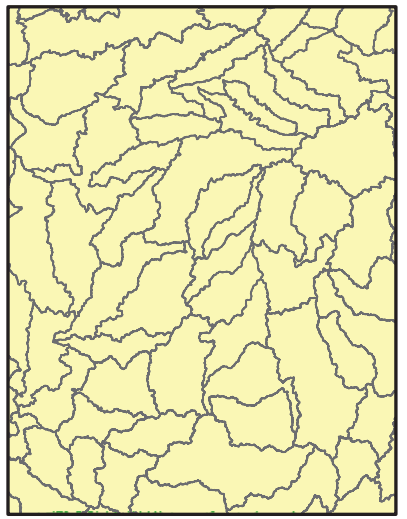

(2) Cultivated cropland National Land Cover Data 2001 land-cover code 82
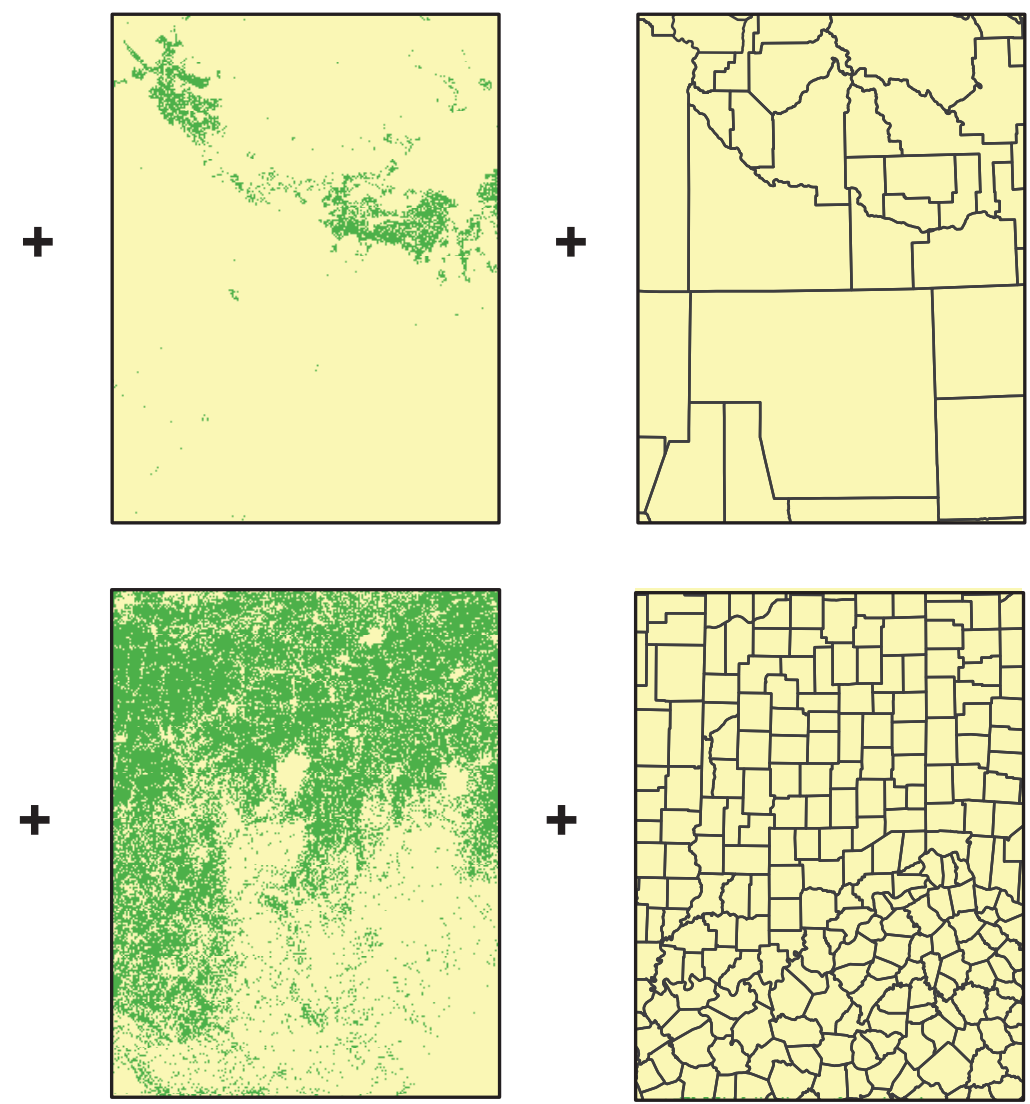

(4) Boundaries for conducting

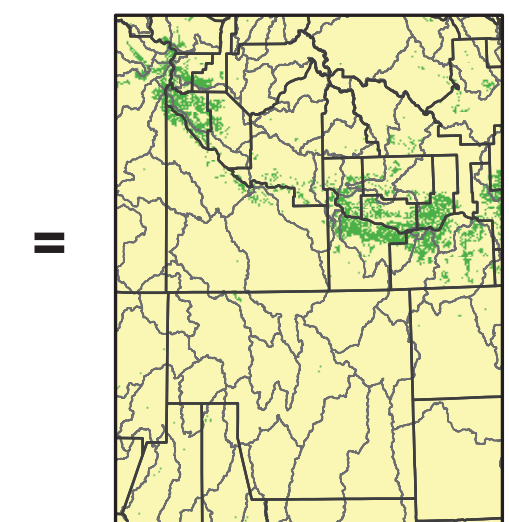

\section{EXPLANATION}

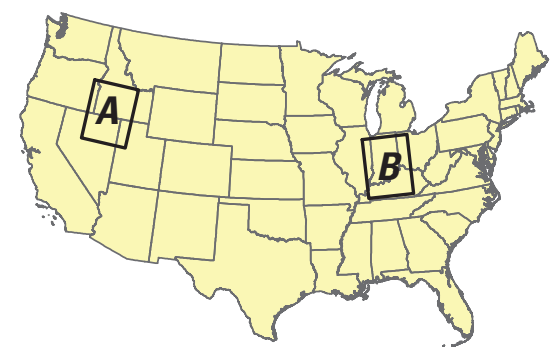

Cultivated cropland

Other land

8-digit hydrologic unit boundary

County boundary land-cover weighted areal interpolation

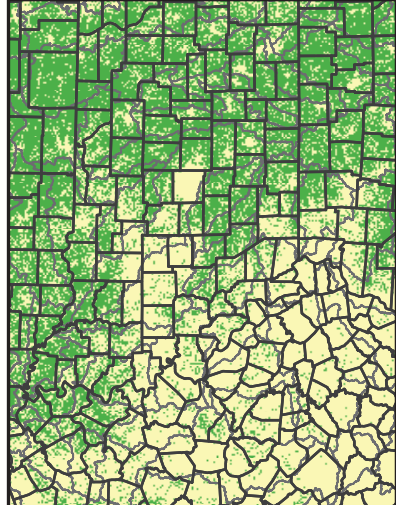

Figure 3. Land-cover weighted areal interpolation by (1) overlaying 8-digit hydrologic unit watersheds with (2) cultivated cropland and (3) county boundaries resulting in (4) the intersection of cultivated land for all the counties in each watershed. Examples of the process are shown for areas in the A western and B eastern United States. 
Table 1. Example output from U.S. Geological Survey National Water-Quality Assessment Area Characterization, Feature Weights to Table Tool

[AREAID, 8-digit hydrologic unit code; ZONE, land cover code; WTZONE, state and county FIPS code; NCELLS, the number of $30 \mathrm{~m}$ X 30m cells with the same AREAID, ZONE, and WTZONE; AREA, the total area of land with the same AREAID, ZONE, and WTZONE (NCELLS X 900); AREAF, area fraction (total area of the unique AREAID - for 3,150,507 total area $=5,082,517,800 \mathrm{~m} 2$ and for 3,150,201 total area $=6,193,173,600 \mathrm{~m} 2$ ); WAREA, weighted area (total area of the unique WTZONE); WAREAF, weighted area fraction (AREA / WAREA); highlighted cells indicate cultivated land (land-cover codes 62 and 82].

\begin{tabular}{|c|c|c|c|c|c|c|c|}
\hline AREAID & ZONE & WTZONE & NCELLS & AREA & AREAF & WAREA & WAREAF \\
\hline 3150107 & 11 & 1001 & 7 & 6300.0 & 0.00000124 & 1565538300.0 & 0.00000402 \\
\hline 3150107 & 21 & 1001 & 173 & 155700.0 & 0.00003063 & 1565538300.0 & 0.00009945 \\
\hline 3150107 & 22 & 1001 & 15 & 13500.0 & 0.00000266 & 1565538300.0 & 0.00000862 \\
\hline 3150107 & 23 & 1001 & 34 & 30600.0 & 0.00000602 & 1565538300.0 & 0.00001955 \\
\hline 3150107 & 25 & 1001 & 13 & 11700.0 & 0.00000230 & 1565538300.0 & 0.00000747 \\
\hline 3150107 & 26 & 1001 & 63 & 56700.0 & 0.00001116 & 1565538300.0 & 0.00003622 \\
\hline 3150107 & 33 & 1001 & 23 & 20700.0 & 0.00000407 & 1565538300.0 & 0.00001322 \\
\hline 3150107 & 41 & 1001 & 10683 & 9614700.0 & 0.00189172 & 1565538300.0 & 0.00614147 \\
\hline 3150107 & 42 & 1001 & 5878 & 5290200.0 & 0.00104086 & 1565538300.0 & 0.00337916 \\
\hline 3150107 & 43 & 1001 & 12418 & 11176200.0 & 0.00219895 & 1565538300.0 & 0.00713889 \\
\hline 3150107 & 62 & 1001 & 68 & 61200.0 & 0.00001204 & 1565538300.0 & 0.00003909 \\
\hline 3150107 & 81 & 1001 & 2846 & 2561400.0 & 0.00050396 & 1565538300.0 & 0.00163611 \\
\hline 3150107 & 82 & 1001 & 4564 & 4107600.0 & 0.00080818 & 1565538300.0 & 0.00262376 \\
\hline 3150107 & 85 & 1001 & 83 & 74700.0 & 0.00001470 & 1565538300.0 & 0.00004772 \\
\hline 3150201 & 11 & 1001 & 23525 & 21172500.0 & 0.00341868 & 1565538300.0 & 0.01352410 \\
\hline 3150201 & 21 & 1001 & 9189 & 8270100.0 & 0.00133536 & 1565538300.0 & 0.00528259 \\
\hline 3150201 & 22 & 1001 & 2257 & 2031300.0 & 0.00032799 & 1565538300.0 & 0.00129751 \\
\hline 3150201 & 23 & 1001 & 4054 & 3648600.0 & 0.00058913 & 1565538300.0 & 0.00233057 \\
\hline 3150201 & 25 & 1001 & 475 & 427500.0 & 0.00006903 & 1565538300.0 & 0.00027307 \\
\hline 3150201 & 26 & 1001 & 6630 & 5967000.0 & 0.00096348 & 1565538300.0 & 0.00381147 \\
\hline 3150201 & 31 & 1001 & 257 & 231300.0 & 0.00003735 & 1565538300.0 & 0.00014774 \\
\hline 3150201 & 33 & 1001 & 27254 & 24528600.0 & 0.00396059 & 1565538300.0 & 0.01566784 \\
\hline 3150201 & 41 & 1001 & 388320 & 349488000.0 & 0.05643116 & 1565538300.0 & 0.22323823 \\
\hline 3150201 & 42 & 1001 & 291453 & 262307700.0 & 0.04235433 & 1565538300.0 & 0.16755112 \\
\hline 3150201 & 43 & 1001 & 451679 & 406511100.0 & 0.06563858 & 1565538300.0 & 0.25966219 \\
\hline 3150201 & 62 & 1001 & 9272 & 8344800.0 & 0.00134742 & 1565538300.0 & 0.00533031 \\
\hline 3150201 & 81 & 1001 & 130100 & 117090000.0 & 0.01890630 & 1565538300.0 & 0.07479217 \\
\hline 3150201 & 82 & 1001 & 224428 & 201985200.0 & 0.03261417 & 1565538300.0 & 0.12901965 \\
\hline 3150201 & 85 & 1001 & 2572 & 2314800.0 & 0.00037377 & 1565538300.0 & 0.00147860 \\
\hline 3150201 & 91 & 1001 & 122314 & 110082600.0 & 0.01777483 & 1565538300.0 & 0.07031613 \\
\hline 3150201 & 92 & 1001 & 8840 & 7956000.0 & 0.00128464 & 1565538300.0 & 0.00508196 \\
\hline
\end{tabular}

A one-to-many relation exists between the county-level tillage data and the cultivated land 8-digit HU/county weighting factors. When the two tables are merged, the weight table is populated with the county-level data so that all the portions of an HU that falls within a single county will be populated with the tillage data for that particular county.

Two dBase files were generated_tillage lu92e.dbf based on the NLCDe 92 (appendix 1) and tillage lu01.dbf based on the NLCD01 (appendix 2). Attribute definitions for the two
dBase files are listed in table 2. The 8-digit HU watershed polygon coverage, $w d b h u c 8$, provides a spatial reference for the tabular tillage data. The numeric value for the 8-digit HU, HUC8 $N$, is used as the unique identifier for the relate attribute between the spatial and tabular data. In the conterminous United States, HU codes range from 01010001 to 18100204. The numeric value for the 8-digit $\mathrm{HU}$ does not include the leading zero for HUs less than 10000000. 
Table 2. Attribute labels and definitions for tillage_lug2e.dbf and tillage_lu01.dbf.

[NA, not applicable; WDBHUC8, water-data boundary 8-digit hydrologic unit code; GIS, Geographic Information System; CTIC, Conservation Technology Information Center]

\begin{tabular}{|c|c|c|c|}
\hline Attribute label & Attribute definition & Units & Source \\
\hline huc8_n & Numeric 8-digit hydrologic unit code identifier & NA & WDBHUC8 GIS coverage \\
\hline crop & Name of crop & NA & CTIC county-level survey \\
\hline year & Year crop was planted & year & CTIC county-level survey \\
\hline notill & $\begin{array}{l}\text { No-till conservation tillage, greater than } 30 \text { percent of soil covered } \\
\text { with crop residue }\end{array}$ & planted acres & area-weighted interpolation \\
\hline ridge & $\begin{array}{l}\text { Ridge-till conservation tillage, greater than } 30 \text { percent of soil covered } \\
\text { with crop residue }\end{array}$ & planted acres & area-weighted interpolation \\
\hline mulch & $\begin{array}{l}\text { Mulch-till conservation tillage, greater than } 30 \text { percent of soil covered } \\
\text { with crop residue }\end{array}$ & planted acres & area-weighted interpolation \\
\hline reduced & $\begin{array}{l}\text { Reduced tillage (not considered conservation tillage), } \\
15 \text { to } 30 \text { percent of crop residue left on soil }\end{array}$ & planted acres & area-weighted interpolation \\
\hline intense & $\begin{array}{l}\text { Intensive or conventional tillage, less than } 15 \text { percent residue left } \\
\text { on soil }\end{array}$ & planted acres & area-weighted interpolation \\
\hline totacre & Total planted acres (sum of all tillage types) & planted acres & calculated \\
\hline petnotil & Percentage of no-till acres (no till / totacre) $* 100$ & percent & calculated \\
\hline pctridge & Percentage of ridge-till acres (ridge till / totacre) $* 100$ & percent & calculated \\
\hline pctmulch & Percentage of mulch-till acres (mulch till / totacre) $* 100$ & percent & calculated \\
\hline pctreduc & Percentage of reduced-till acres (reduced till / totacre) $* 100$ & percent & calculated \\
\hline pctinten & Percentage of intensive-till acres (intensive till / totacre) $* 100$ & percent & calculated \\
\hline
\end{tabular}

\section{Tillage-Practice Datasets Aggregated to 8-Digit Hydrologic Unit Watersheds}

In order to evaluate the results of aggregating countylevel tillage surveys to the 8-digit HUs, manual calculations of selected HUs were made to ensure that the automated interpolation was done correctly, and the original county-level data were compared to the 8-digit HU aggregation to ensure that the results of the aggregation reliably reflect the original data. In addition, the original data were compared to other independently collected data.

Aggregated data for selected HUs were compared to values manually calculated for the associated CTIC county and crop acreages. Manual calculation of weighting factors and application to CTIC tillage-practice acreages for the counties within selected HUs shows that the automated procedures for the cultivated-land area-weighted interpolation performed the interpolation and aggregation correctly.

Visually comparing the results of the original countylevel data with the aggregated data indicates that the aggregation to an 8-digit $\mathrm{HU}$ watershed reliably reflects the original data (fig. 4). Slight differences exist between the county-level and HU-level data. In the west where counties generally are larger than 8-digit HU watersheds, the shaded areas on the county map may extend to a larger area than that shown on the watershed map. Conversely, in areas where the counties are smaller than 8-digit HU watersheds, the shaded areas on the watershed map cover a larger extent than on the county map (fig. 4).

Comparisons were made of the original CTIC data to independently collected State-level tillage data. The U.S. Department of Agriculture (USDA)-Economic Research Service (ERS) compiles limited State-level tillage data for selected states and crops from 1990 through 2000 (fig. 5). The ERS conducts farm surveys from a representative sample of farms to estimate the percentage of tillage practices for the State and then multiplies the percentage of each tillage practice by NASS estimates of crop acreage (U.S. Department of Agriculture-Economic Research Service, 1997 and 2010). The CTIC uses a similar method but conducts their surveys independently from the ERS. A graphical comparison for selected crops and years between the CTIC and ERS tillage data shows good agreement between the two datasets at the State level (fig. 5). 


\section{County}

\section{8-digit hydrologic unit watershed}

\section{A. All crops}
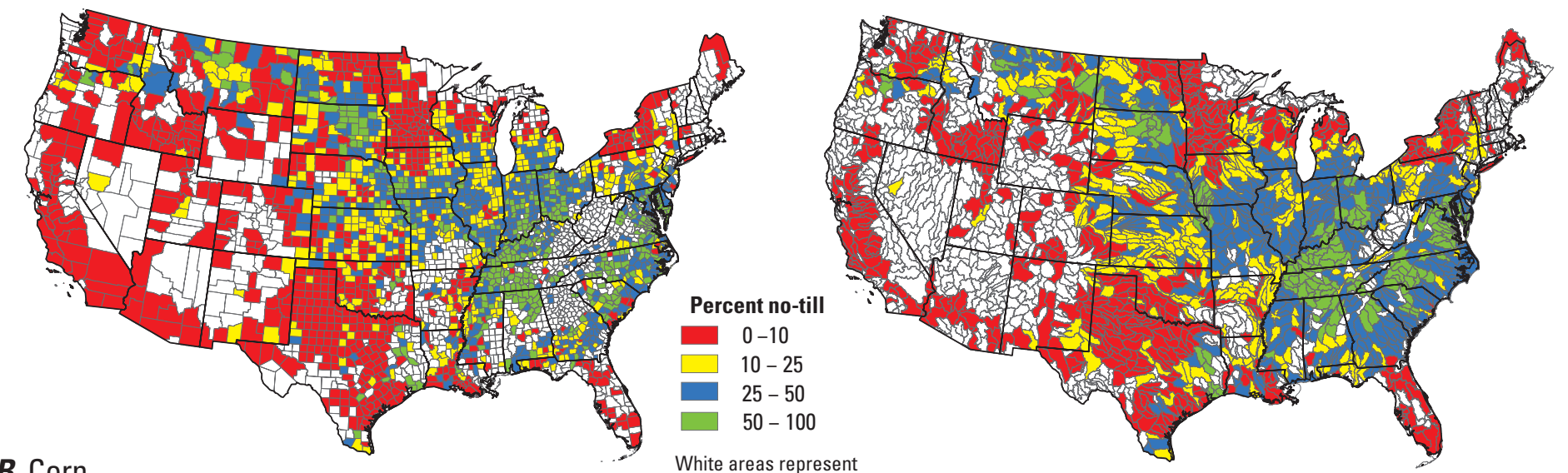

B. Corn

White areas represent

counties with less than
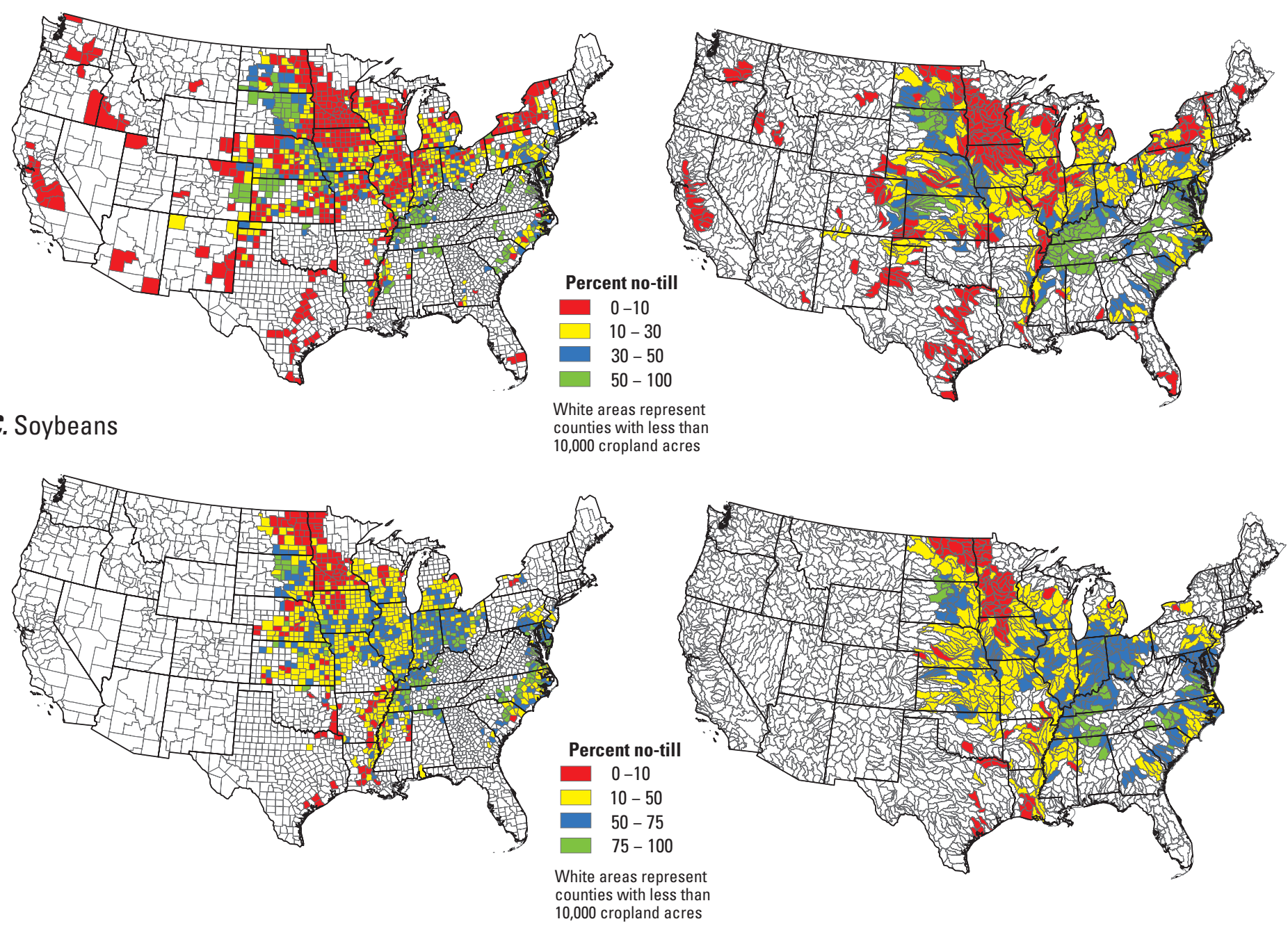

Figure 4. Comparison of the original Conservation Technology Information Center county-level data and 8-digit hydrologic unit watershed-level data for the percentage of no-till on $A$ all crops, $B$ corn, and $C$ soybeans for the conterminous United States, 2004 

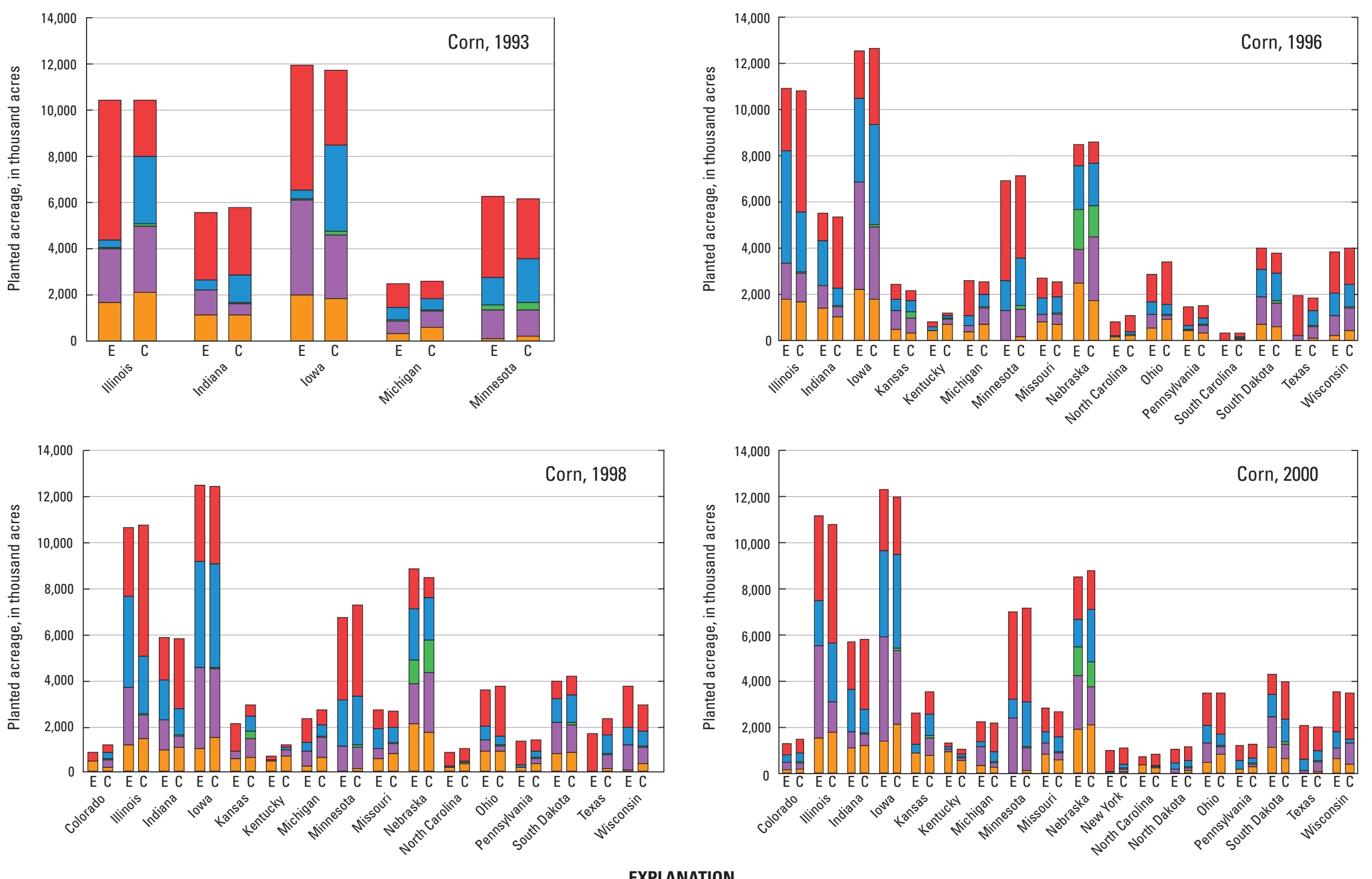

\section{EXPLANATION}

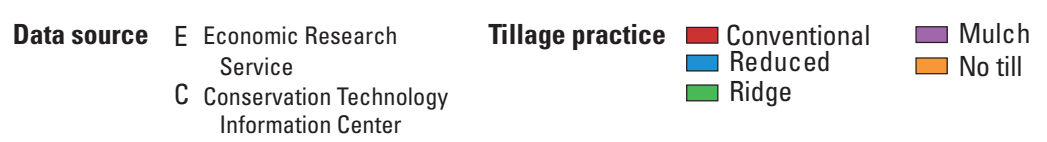

$\begin{array}{rlr}\text { Tillage practice } & & \begin{array}{l}\text { Conventional } \\ \text { Reduced }\end{array} \\ & \square \text { Mulch } \\ \text { Ridge } & & \square \text { No till }\end{array}$

Figure 5. Comparison of Economic Research Service (E) and Conservation Technology Information Center (C) estimates of total planted acreages, by State, and tillage practice for corn for 1993, 1996, 1998, and 2000. [Source: U.S. Department of Agriculture-Economic Research Service, 1997 and 2010; Karen Scanlon, Executive Director, Conservation

Technology Information Center, written commun., 2010] 

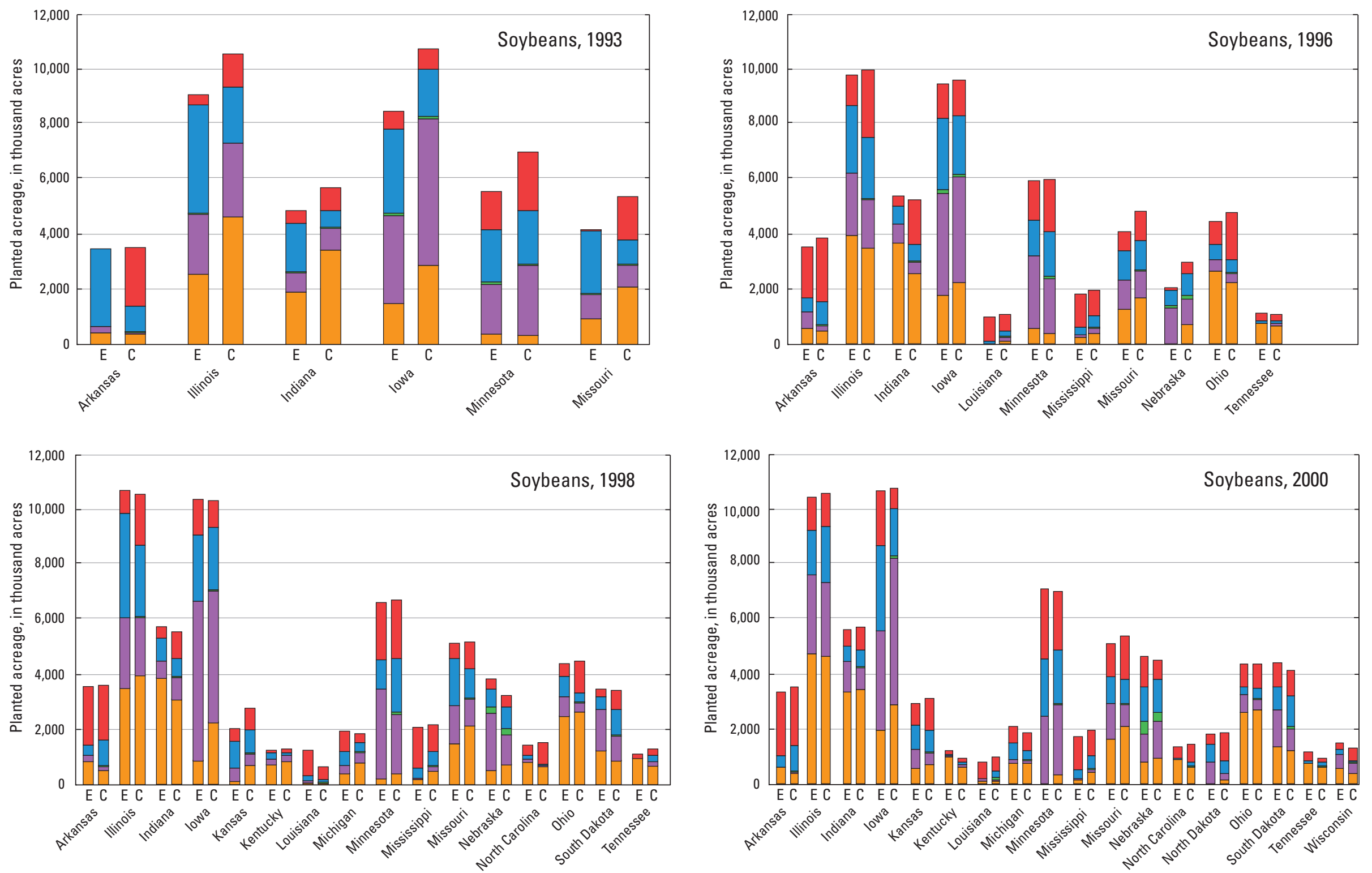

\section{EXPLANATION}

\begin{tabular}{|c|c|c|c|}
\hline Data source & $\begin{array}{l}\text { E Economic Research } \\
\text { Service } \\
\text { C Conservation Technology }\end{array}$ & Tillage practice & $\begin{array}{l}\square \text { Conventional } \\
\square \text { Reduced } \\
\square \text { Ridge }\end{array}$ \\
\hline
\end{tabular}

Figure 5 (cont). Comparison of Economic Research Service (E) and Conservation Technology Information Center (C) estimates of total planted acreages, by State, and tillage practice for soybeans for 1993, 1996, 1998, and 2000. [Source: U.S. Department of Agriculture-Economic Research Service, 1997 and 2010; Karen Scanlon, Executive Director, Conservation Technology Information Center, written commun., 2010] 


\section{Summary}

The Conservation Technology Information Center (CTIC) proprietary county-level tillage data were aggregated to 8-digit hydrologic unit (HU) watersheds and made available for inclusion in U.S. Geological Survey (USGS), National Water-Quality Assessment (NAWQA) supported analyses. A cultivated-land area-weighted interpolation, based on the 1992 enhanced and 2001 National Land Cover Data (NLCDe 92) and (NLCD01), respectively, was done to calculate weighting factors for each county/HU combination. Weighting factors then were multiplied by county-level tillage data and aggregated by $\mathrm{HU}$ to yield tillage-practice acreages for selected crops for each 8-digit HU in the conterminous United States. Two tabular datasets were generated and included planted acreage of conservation tillage (includes no-till, ridge-till, and mulch-till), reduced tillage, and intensive or conventional tillage for selected crops (corn, cotton, grain sorghum, soybeans, fallow, forage, newly established permanent pasture, spring and fall seeded small grains, and "other" crops) by HU for 1989-2004.

The 8-digit HU watershed polygon coverage is the spatial reference for the two tabular datasets. The tabular datasets can be related to the watershed polygons by the numeric value of the unique 8-digit HU code ( $\left.H U C 8 \_N\right)$.

Comparison of results for 8-digit $\mathrm{HU}$ watershed aggregation and the original county-level data shows that the aggregation reliably reflects the original data. Manual calculations of weighting factors for selected HUs were done to ensure the automated calculations were done correctly. Comparison of the original data with tillage data independently collected by the Economic Research Service also was done.

\section{References Cited}

Conservation Technology Information Center, 2004, 2004 National crop residue management survey: Conservation Technology Information Center, West Lafayette, Ind., accessed September 2009 at www.ctic.purdue.edu.

Conservation Technology Information Center, 2007, Tillage type definitions: Conservation Technology Information Center, West Lafayette, Ind., accessed September 2009 at http://www.ctic.purdue.edu/media/pdf/TillageDefinitions.pdf
LaMotte, Andrew, 2008, National land cover database 2001 (NLCD01), Tiles 1-4: U.S. Geological Survey Data Series 383a, accessed November 2008 at http://water.usgs.gov/ GIS/metadata/usgswrd/XML/nlcd01_1.xml.

Nakagaki, Naomi, Price, C.V., Falcone, J.A., Hitt, K.J., and Ruddy, B.C., 2007, Enhanced national land cover data 1992 (NLCDe 92), Tiles 1-4: U.S. Geological Survey digital raster data, accessed June 2010 at http://water.usgs.gov/GIS/ metadata/usgswrd/XML/nlcde92.xml.

Price, C.V., Nakagaki, Naomi., and Hitt, K.J., 2010, The National Water-Quality Assessment (NAWQA) Area-Characterization Toolbox, Release 1.0: U.S. Geological Survey Open-File Report 2010-1268, accessed June 2010 at http://pubs.usgs.gov/of/2010/1268.

U.S. Department of Agriculture, Economic Research Service, 1997, Cropping practices, 1990-95, accessed September 2010 at http://www.ers.usda.gov/data/archive/93018/.

U.S. Department of Agriculture, Economic Research Service, 2010, Farm Business and Household Survey data: Customized Data Summaries from ARMS, Tailored Reports, Crop Production Practices, accessed September 2010 at http://www.ers.usda.gov/Data/ARMS/app/default. aspx? survey $=$ CROP\#startForm

U.S. Geological Survey, 2008a, (NLCD) 1992/2001 retrofit land cover change product multi-zone download site, Multi-Resolution Land Characteristics Consortium (MRLC), National Land Cover Database, accessed September 2010 at http://www.mrlc.gov/multizone.php.

U.S. Geological Survey, 2008b, NLCD 2001 land cover class definitions, Multi-Resolution Land Characteristics Consortium (MRLC), National Land Cover Database, accessed September 2010 at http://www.mrlc.gov/nlcd_definitions.php.

U.S. Geological Survey, 2010, NLCD land cover class definitions, The USGS Land Cover Institute, accessed September 2010 at http://landcover.usgs.gov/classes.php.

U.S. Geological Survey and U.S. Department of AgricultureNatural Resources Conservation Service, 2009, Federal guidelines, requirements, and procedures for the national Watershed Boundary Dataset: U.S. Geological Survey Techniques and Methods 11-A3, 55 p., report available at http://pubs.usgs.gov/tm/tm11a3/; geospatial data accessed November 2009 at http://www.ncgc.nrcs.usda.gov/products/ datasets/watershed/. 


\section{Appendixes 1-3. Tillage Practices in the Conterminous United States, 1989-2004- Datasets Aggregated by Watershed}

1. This dBase tabular dataset is based on the 1992 enhanced National Land Cover Data. This dataset is intended to be used with the 8-digit watershed boundary data (WBDHUC8, provided below) which shares the common attribute HUC8_N. This tabular data can be linked (joined or related) to the WBDHUC8 dataset by the HUC8_N attribute.

Download data here: http://water.usgs.gov/GIS/metadata/usgswrd/XML/ds573_tillage_lu92e.xml

2. This dBase tabular dataset is based on the 2001 National Land Cover Data. This dataset is intended to be used with the 8-digit watershed boundary data (WBDHUC8, provided below) which shares the common attribute HUC8_N. This tabular data can be linked (joined or related) to the WBDHUC8 dataset by the HUC8_N attribute.

Download data here: http://water.usgs.gov/GIS/metadata/usgswrd/XML/ds573_tillage_lu01.xml

3. This is the companion dataset to be used with the tabular dBase tillage practice datasets above. The WBDHUC8 is derived from the 12-digit Watershed Boundary Data and includes the attribute HUC8_N. HUC8_N is the common attribute used to link the tabular dBase data files above to this geospatial dataset.

Download the WBDHUC8 here: http://water.usgs.gov/GIS/metadata/usgswrd/XML/ds573_wbdhuc8.xml 


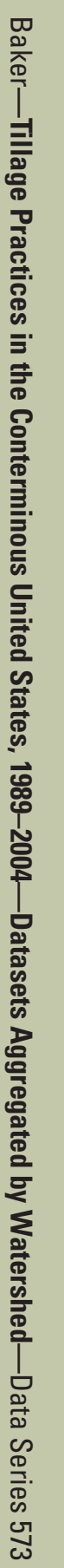

